\title{
MENAKAR PROGRESIFITAS LEMBAGA PERADILAN DALAM MEWUJUDKAN DEMOKRASI BERINTEGRITAS
}

Oleh:

\author{
Alda Rifada Rizqi, S.H., M.H.* \\ Email: Aldarifada.rizqi@yahoo.com
}

Abstract

Democracy with integrity will be realized if carried out in accordance with the will of the people as holders of sovereignty, the KPU (Komisi Pemilihan Umum) as the election organizer has the authority to make regulations that support a better democracy. KPU (Komisi Pemilihan Umum) Regulation No. 20 of 2018 as evidence that the KPU is committed to participating in preventing corrupt behavior. It was considered to have been considered as an effort to protect the interests of the people, but the regulation was submitted to a judicial review at the Supreme Court. Then, based on legal-formal considerations and based on the legal positivism of the Supreme Court, the request for the test is granted. The decision distanced itself from progressive legal values that justified the denial of what was regulated in legislation in order to put forward the values of public justice, because basically the law was made to fulfill human interests, accommodating the will of the people for the sake of order.

Keywords: Progressive Law, Decision of the Supreme Court.

\section{A. PENDAHULUAN}

Pemilihan umum (pemilu) adalah sarana demokrasi yang dari padanya dapat ditentukan siapa yang berhak menduduki kursi di lembaga politik negara, legislatif dan/atau eksekutif. Oleh Jimly Asshiddiqie, pemilu diartikan sebagai mekanisme penentuan pendapat rakyat melalui mekanime yang bersifat langsung. ${ }^{1}$ Melalui pemilu rakyat memilih figur

\footnotetext{
*Dosen Tetap Sekolah Tinggi Hukum Bandug (STHB), Bandung.

1 Dedi Mulyadi, Perbandingan Tindak Pidana Pemilu Legislatif Dalam Perspektif Hukum di Indonesia, Bandung, Refika Aditama, 2013, hlm. 59.
}

yang dipercaya untuk mengisi jabatanjabatan tersebut. Pemilu merupakan sarana demokrasi untuk membentuk sistem kekuasaan negara yang berkedaulatan rakyat. Pemilu dilaksanakan berdasarkan prinsip atau asas yang diatur dalam UndangUndang Dasar Negara Republik Indonesia Tahun 1945 (UUD NRI 1945). Pasca perubahan ketiga UUD NRI 1945, dalam Pasal 22E Ayat (1) dinyatakan bahwa penyelenggaraan pemilu dilaksanakan secara langsung, umum, bebas, rahasia, jujur dan adil setiap lima tahun sekali. Salah satu 
tolok ukur demokratis atau tidaknya pemilu adalah adanya lembaga penyelenggara pemilu yang mandiri. Hal tersebut ditegaskan dalam Pasal 22E Ayat (5) UUD NRI 1945, bahwa pemilu diselenggarakan oleh suatu komisi pemilihan umum yang bersifat nasional, tetap dan mandiri.

Kewenangan Komisi Pemilihan Umum (KPU) lebih lanjut diatur dalam Undang-Undang Nomor 7 Tahun 2017 tentang Pemilihan Umum (UU Pemilu). Pengaturan tersebut memberikan tugas dan wewenang kepada KPU dalam menjalankan amanat konstitusi untuk menyelenggarakan pemilu. Dalam menjalankan amanat konstitusi tersebut, KPU diberikan kewenangan untuk menetapkan peraturan KPU dalam setiap tahapan pemilu. Atas dasar itu, dan untuk mewujudkan pemilu yang berintegritas KPU mengeluarkan Peraturan Komisi Pemilihan Umum Nomor 20 Tahun 2018 tentang Pencalonan Anggota Dewan Perwakilan Rakyat (DPR), Dewan Perwakilan Rakyat Daerah (DPRD) Provinsi dan DPRD Kabupaten/Kota, yang salah satu ketentuannya menyebutkan bahwa setiap partai politik harus melakukan seleksi bakal calon anggota DPR, DPRD Provinsi dan DPRD
Kabupaten/ Kota secara demokratis dan terbuka sesuai dengan Anggaran Dasar dan Anggaran Rumah Tangga (AD/ ART) partai politik masingmasing dan/atau ketentuan internal masing-masing partai politk. Dalam seleksi tersebut, KPU memberikan batasan kepada partai politik untuk tidak menyertakan mantan terpidana bandar narkoba, kejahatan seksual terhadap anak dan tindak pidana korupsi.

Pembatasan tersebut bukan tanpa alasan, melainkan didasarkan pada konstruksi berpikir bahwa lembaga parlemen baik di pusat maupun di daerah harus diisi oleh orang-orang yang memiliki integritas tinggi dan merupakan orang pilihan dan mempunyai rekam jejak yang baik, karena selanjutnya orang tersebut akan bertugas untuk dan atas nama rakyat. Namun kemudian, berdasarkan ketentuan pasal 24A Ayat (1) UUD NRI 1945, Peraturan KPU Nomor 20 Tahun 2018 diajukan uji materi ke Mahkamah Agung (MA), dan berdasarkan permohonan tersebut MA membatalkan Peraturan KPU NoMOR 20 Tahun 2018 tersebut karena dianggap bertentangan dengan ketentuan Pasal 240 ayat (1) huruf g dan Pasal 182 huruf g UU Pemilu. Selain itu MA juga mengabulkan 
gugatan uji materi terhadap Pasal 60 huruf (j) Peraturan KPU Nomor 26 Tahun 2018 tentang Pencalonan Anggota Dewan Perwakilan Daerah (DPD).

Putusan MA tersebut dinilai kontraproduktif di tengah gencarnya pemerintah melakukan upaya-upaya pemberantasan korupsi di berbagai level pemerintahan. Niat baik KPU dalam melakukan upaya mewujudkan demokrasi yang bersih - dengan mengeluarkan peraturan syarat pencalonan yang bukan mantan narapidana narkoba, kekerasan seksual terhadap anak dan korupsi - seolah dikalahkan Putusan MA yang didasarkan pada alasan formal prosedural dan menjauhkan diri dari nilai-nilai substansial. Menjadi hal yang menarik bagi penulis untuk menganilisis bagaimanakah pandangan hukum progresif terhadap Putusan MA tersebut. Meskipun tulisan ini banyak memliki kekurangan, semoga tulisan ini bisa sedikit memberikan sumbangsih pemikiran bahwa seyogyanya kehidupan berhukum kita tidak harus selalu berada dalam pemikiran yang formal-prosedural melainkan hukum harus menjangkau ke arah nilai-nilai substansial.

\section{B. PEMBAHASAN}

Sebagai bukti pengejawantahan daulat rakyat yang diamanatkan oleh konstitusi Indonesia, demokrasi sudah berjalan di negara ini. Telaah tentang tolak-tarik antara peranan negara dan masyarakat tidak dapat dilepaskan dari telaah tentang demokrasi, karena dua alasan. Pertama, hampir semua negara di dunia telah menjadikan demokrasi sebagai asasnya yang fundamental sebagai telah ditunjukkan oleh United Nations Educational, Scientific and Cultural Organization (UNESCO) pada awal 1950-an yang mengumpulkan lebih dari 100 sarjana Barat dan Timur, sementara di negaranegara demokrasi itu pemberian peran kepada negara dan masyarakat hidup dalam porsi yang beda-beda (kendati sama-sama demokrasi). Kedua, demokrasi sebagai asas kenegaraan secara esensial telah memberikan arah bagi peranan masyarakat untuk menyelenggarakan negara sebagai organisasi tertinggi tetapi ternyata demokrasi itu berjalan dalam rute yang berbeda-beda. ${ }^{2}$

Demokrasi mempunyai arti penting bagi masyarakat yang menggunakannya sebab dengan

\footnotetext{
2 M. Amien Rais, sebagaimana dikutip oleh Moh. Mahfud MD, Demokrasi dan Konstitusi di Indonesia, Rineka Cipta, Jakarta, 2003, hlm. 6.
} 
demokrasi hak masyarakat untuk menentukan sendiri jalannya organisasi negara dijamin. Demokrasi sebagai dasar hidup bernegara memberi pengertian bahwa pada tingkat terakhir rakyat memberikan ketentuan dalam masalah-masalah pokok yang mengenai kehidupannya, termasuk dalam menilai kebijaksanan negara, oleh karena kebijaksanaanya itu menentukan kehidupan rakyat. Dengan demikian, negara demokrasi adalah negara yang diselenggarakan berdasarkan kehendak dan kemauan rakyat, atau jika ditinjau dari sudut organisasi ia berarti suatu pengorganisasian negara yang dilakukan oleh rakyat sendiri atau atas persetujuan rakyat karena kedaulatan berada ditangan rakyat.

Seperti hal pada umumnya, organisasi dapat berjalan dengan baik apabila struktural keorganisasian diisi oleh sumber daya manusia yang baik juga. Sebagaimaa dikatakan bahwa negara merupakan kekuasaan terorganisasi yang mengatur masyarakat hukum untuk mewujudkan tujuan-tujuan tertentu demi kesejahteraan bersama. ${ }^{3}$ Di Indonesia, secara konstitusional proses pengisian

${ }^{3}$ I Gde Pantja Astawa dan Suprin Na'A, Memahami Ilmu Negara \& Teori Negara, Refika Aditama, Bandung, 2015, hlm. 25. jabatan-jabatan organisasi kenegaraan dilakukan melalui pemilu berdasarkan pada kehendak penuh yang dimiliki oleh rakyat, hal ini didasarkan pada prinsip bahwa daulat rakyat sebagaimana dalam UUD NRI 1945, menjadi dasar pengejawantahan demokrasi melalui pemilu yang langsung, umum, bebas, rahasia, jujur, dan adil.

Visi tentang negara demokratis secara sederhana dipahami dengan hadirnya kehidupan politik hukum yang bermuara pada terbentuknya pemerintahan yang demokratis. Proses lahirnya pemerintahan demokratis berawal dari konsolidasi demokrasi yang berlangsung secara regular melalui mekanisme pemilu. Demokratisasi pemilu untuk memastikan seleksi dan rekruitmen kepemimpinan dalam sebuah konstestasi yang terbuka, transparan dan akuntabel. Selain terpenuhinya hak-hak masyarakat sebagai pemilih, pemilu yang demokratis juga menghendaki adanya keadilan dalam proses pelaksanaan pemilihan.

UUD NRI 1945 menegaskan bahwa negara Indonesia adalah negara hukum. ${ }^{4}$ Hal ini pada berarti bahwa negara Indonesia berdasarkan atas

\footnotetext{
${ }^{4}$ Pasal 1 ayat (3) UUD NRI 1945.
} 
hukum (rechstaat) bukan berdasarkan atas kekuasaan belaka (machtsstaat).

Seiring dengan hal tersebut, salah satu prinsip penting dalam negara hukum adalah adanya penyelenggaraan pemilu yang merdeka dan bebas dari pengaruh kekuasaan lainnya untuk menyelenggarakan pemilu. Penyelenggaraan pemilu tersebut diselenggarakan oleh sebuah komisi yaitu KPU.

Secara kelembagaan, KPU merupakan lembaga negara yang dibentuk oleh undang-undang tidak bisa disamakan kedudukannya dengan lembaga negara lain yang kewenangannya ditentukan, disebut dan diberikan oleh UUD NRI $1945 .^{5}$ Kedudukan KPU hanya dianggap sederajat dengan lembaga yang dibentuk oleh undang-undang, tetapi UUD NRI 1945 menjamin keberadaanya karena lembaga penyelenggara pemilu disebut dalam pasal 22E.

Menurut Kamus Praktis Bahasa Indonesia yang disusun oleh A.A. Waskito, kata kewenangan memiliki arti hak dan kekuasaan yang dipunyai untuk melakukan sesuatu. Istilah kewenangan tidak dapat disamakan

5 Jimly Asshidiqie, Perkembangan dan Konsolidasi Lembaga Negara Pasca Reformasi, Sekretaris Jendral dan Kepaniteraan Mahkamah Konstitusi RI, Jakarta, 2006, hlm. 233. dengan istilah urusan karena kewenangan dapat diartikan sebagai hak dan atau kewajiban untuk menjalankan satu atau beberapa fungsi manajemen (pengaturan, perencanaan, pengorganisasian, pengurus dan pengawasan) atas suatu obyek tertentu yang ditangani oleh pemerintahan. ${ }^{6}$

Philipus M. Hadjon dalam bukunya Pengantar Hukum Administrasi Indonesia, dinyatakan bahwa istilah wewenang disejajarkan dengan istilah "bevoegheid". Sementara menurut pandangan H.D. Stout, dalam Ridwan H.R., menyebutkan bahwa wewenang (bevoegheid) berasal dari hukum organisasi pemerintahan, ${ }^{8}$ menurut Bagir Manan bahwa kewenangan merupakan kekuasaan menggambarkan hak untuk berbuat atau tidak berbuat. ${ }^{9}$

Dalam perspektif Hukum Administrasi Negara, sumber

\footnotetext{
${ }^{6}$ Agussalim, Pemerintah Daerah Kajian Politik dan Hukum, Ghalia, Bogor, 2007, hlm. 95.

${ }^{7}$ Philipus M. Hadjon, Pengantar Hukum Administrasi Indonesia-Introduction to Indonesian Administrative Law: Gadjah Mada University Press, Yogyakarta, 2002, hlm. 1.

8 Ridwan HR, Hukum Administrasi Negara, Raja Grafindo Persana, Jakarta, 2006, hlm. 101 .

9 Bagir Manan, Wewenang Provinsi, Kabupaten dan Kota dalam Rangka Otonomi Daerah, Makalah pada Seminar Nasional Pengembangan Wilayah dan Pengelolaan Sumber Daya Alam di Kawasan Pesisir dalam Rangka Penataan Ruang, Fakultas Hukum Universitas Padjajaran Bandung, 13 Mei 2001, hlm. 1-2.
} 
kekuasaan dan wewenang bagi pemerintah adalah peraturan perundang-undangan. Adapun yang dapat diberikan kepada pihak tertentu melalui tiga cara yaitu atribusi, delegasi dan mandat.

1. Atribusi (attributie) adalah wewenang pemerintahan oleh pembuat undang-undang kepada organ pemerintahan,

2. Delegas (delegatie) adalah pelimpahan wewenang pemerintahan dari suatu organ pemerintahan ke organ pemerintahan lainnya,

3. Mandat (mandaat) adalah pelimpahan wewenang yang terjadi apabila suatu organ pemerintahan mengizinkan kewenangannya dijalankan oleh lembaga lain atas namanya. $^{10}$

Keberadaan KPU yang terbentuk berdasarkan UUD NRI 1945 tentu terkait dengan fungsi, tugas dan wewenang serta tanggungjawab, mengingat KPU yang bersifat nasional, tetap dan mandiri. Memfokuskan kajian terhadap kewenangan yang dimiliki KPU, Pasal 13 UU Pemilu memberikan kewenangan kepada KPU yang di antaranya adalah :

\footnotetext{
${ }^{10}$ Op.,Cit., hlm. 129
}

1. Menetapkan tata keraja KPU, KPU Provinsi, KPU Kabupaten/ Kota, Panitia Pemilihan Kecamatan (PPK), Panitia Pemungutan Suara (PPS), Kelompok Penyelenggara Pemungutan Suara (KPPS) dan Kelompok Penyelenggara Pemungutan Suara Luar Negeri (KPPSLN);

2. Menetapkan Peraturan KPU untuk setiap tahapan pemilu;

3. Menetapkan peserta pemilu;

4. Menetapkan dan mengumumkan hasil rekapitulasi penghitungan suara tingkat nasional berdasarkan hasi rekapitulasi penghitungan suara di KPU Provinsi untuk Pemilu Presiden dan Wakil Presiden dan untuk Pemilu anggota DPR serta hasil rekapitulasi penghitungan suara KPU Provinsi untuk pemilu anggota DPD dengan membuat berita acara penghitungan suara dan sertifikat hasil penghitungan hasil suara;

5. Menerbitkan keputusan KPU untuk mengesahkan hasil pemilu dan mengumumkannya;

6. Menetapkan dan mengumumkan perolehan jumlah kursi anggota DPR, anggota DPRD Provinsi, dan anggota DPRD kabupaten/kota untuk setiap partai politik peserta pemilu anggota DPR, anggota 
DPRD Provinsi, dan anggota DPRD kabupaten/kota;

7. Menetapkan standar serta kebutuhan pengadaan dan pendistribusian perlengkapan;

8. Membentuk KPU Provinsi, KPU Kabupaten/Kota, dan Panitia Pemilihan Luar Negeri (PPLN);

9. Mengangkat, membina dan memberhentikan anggota KPU Provinsi, anggota KPU Kabupaten/ Kota, dan anggota PPLN;

10. Menjatuhkan sanksi administratif dan/atau menonaktifkan sementara anggota KPU Provinsi, anggota KPU Kabupaten/Kota, anggota PPLN, anggota KPPSLN, dan Sekretaris Jenderal KPU yang terbukti melakukan tindakan yang mengakibatkan terganggunya tahapan penyelenggaraan pemilu yang sedang berlangsung berdasarkan putusan Badang Pengawas Pemilan Umum (Bawaslu) dan/atau ketentuan peraturan perundang-undangan;

11. Menetapkan kantor akuntan publik untuk mengaudit dana kampanye pemilu dan mengumumkan laporan sumbangan dan kampanye pemilu; dan

12. Melaksanakan wewenang lain dalam penyelenggaraan pemilu sesuai dengan ketentuan peraturan perundang-undangan.

Lebih lanjut, apabila melihat ketentuan Pasal 8 Undang-Undang Nomor 12 Tahun 2011 tentang Pembentukan Peraturan PerundangUndangan yang menyatakan :

1. Jenis peraturan perundangundangan selain sebagaimana dimaksud dalam Pasal 7 Ayat (1) mencakup peraturan yang ditetapkan oleh Majelis Permusyawaratan Rakyat (MPR), DPR, DPRD, MA, Mahkamah Konstitusi (MK), Badan Pemeriksa Keuangan (BPK), Komisi Yudisial (KY), Bank Indonesia (BI), menteri, badan, lembaga atau komisi yang setingkat yang dibentuk dengan undang-undang atau perintah atas undang-undang, DPRD Provinsi, Gubernur, DPRD Kabupaten/Kota, Bupati/Wali Kota, Kepala Desa atau yang setingkat.

2. Peraturan perundang-undangan sebagaimana dimaksud pada ayat (1) diakui keberadaanya dan mempunyai kekuatan hukum mengikat sepanjang diperintahkan oleh peraturan perundangundangan yang lebih tinggi atau dibentuk berdasarkan kewenangan. 
Melihat dua ketentuan tersebut di atas, secara formal prosedural, Peraturan KPU dibuat berdasarkan kewenangan karena didasarkan pada alasan peraturan tersebut dibuat oleh lembaga yang dibentuk berdasarkan undang-undang, KPU mempunyai kewengan atributsi yang langsung diberikan oleh undang-undang dalam hal membuat Peraturan KPU, maka dikeluarkannya Peraturan KPU Nomor 20 Tahun 2018 tentang Pencalonan anggota DPR, DPRD Provinsi dan DPRD Kabupaten/Kota sudah sesuai dengan kewenangan yang dimiliki dan diakui sebagai ketentuan peraturan perundang-undangan yang mengikat.

Peraturan KPU tersebut dibuat sejalan dengan tujuan dan cita hukum bangsa dan negara Indonesia dalam rangka mewujudkan masyarakat yang adil dan makmur berdasarkan Pancasila dan UUD NRI 1945, KPU memiliki semangat, kewajiban dan tanggungjawab yang bulat dan utuh dalam rangka mewujudkan penyelenggara negara yang kuat dan warga negara yang berdaulat. Syarat urama mewujudkan hal tersebut tidak lain adalah dengan mewujudkan negara bersih dan terbebas dari korupsi, kolusi dan nepotisme yang telah merusak sendi-sendi kehidupan bermasyarakat, berbangsa dan bernegara serta membahayakan eksistensi negara sejak dahulu sampai sekarang.

Peraturan ini juga dibuat dengan alasan bahwa korupsi memiliki kecenderungan pola yang berulang dan bahkan bermetamorfosa. Dari data yang dihimpun oleh Indonesian Corruption Watch (ICW) menunjukkan bahwa fenomena residivis korupsi atau orang yang pernah dijatuhi hukuman dalam perkara korupsi lalu kembali melakukan korupsi setelah selesai menjalani hukuman beberapa kali terjadi. Tercatat misalnya di Samarinda oleh Aidil Fitra/Ketua Komite Olahraga Nasional Indonesia (KONI) Samarinda, Jawa Timur oleh Muhammad Basuki/ Ketua DPRD Jawa Timur dan di Hulu Sungai Tengah oleh Abdul Latif/ Bupati Hulu Sungai Tengah. ${ }^{11}$

Oleh karenanya melakukan langkah antisipasi secara tegas dengan melakukan upaya pencegahan melalui formulasi Peraturan KPU menjadi sangat beralasan secara sosial bahkan amat penting bagi penyelenggaraan negara ke depan. Karena bagaimanapun, pelaku-pelaku korupsi

${ }^{11}$ Lihat
https://www.antikorupsi.org.id/siaran-pers/kpu-


tidak dapat lagi ditoleransi untuk masuk kembali duduk dan memegang kewenangan dalam lembaga negara dan pemerintahan baik di pusat maupun di daerah. Negara dengan demikian menanggung risiko terlalu tinggi jika tidak ada upaya pencegahan dari awal dan masih memberi kesempatan kepada perbuatan korupsi melalui para pelakunya yang berperan dalam lembaga negara dan pemerintahan.

Namun kemudian, seiring dengan dinamika dan perkembangan masyarakat, tidak lama setelah Peraturan KPU Nomor 20 Tahun 2018 disahkan, permohonan uji materi diajukan oleh salah seorang warga negara Indonesia kepada MA, uji materi ditujukan pada ketentuan Pasal 4 Ayat (3) yang b menyatakan bahwa "Dalam seleksi bakal calon secara demokratis dan terbuka sebagaimana dimaksud pada ayat (2), tidak menyertakan mantan narapidana bandar narkoba, kejahatan seksual terhadap anak dan korupsi”, kemudian melalui Putusan Nomor 46 P/HUM/2018 MA mengabulkan permohonan pemohon yang pada pokoknya meminta agar MA membatalkan ketentuan tersebut. MA mengabulkan permohonan tersebut dengan alasan bawha Pasal 4 ayat (1)
Peraturan KPU Nomor 20 Tahun 2018 dianggap bertentangan dengan Pasal 43 ayat (1) Undang-Undang Nomor 39 Tahun 1999 tentang Hak Asasi Manusia yang menyebutkan "Setiap warga negara berhak dipilih dan memilih dalam pemilu berdasarkan persamaan hak melalui pemungutan suara yang langsung, umum, bebas, rahasia, jujur, dan adil sesuai dengan ketentuan peraturan perundangundangan" dan Pasal 73 yang menyebutkan "Hak dan kebebasan yang diatur dalam undang-undang ini hanya dapat dibatasi oleh dan berdasarkan undang-undang, semata untuk menjamin pengakuan dan pengormatan terhadap hak asasi manusia serta kebebasan dasar lain, kesusilaan, ketertiban umum, dan kepentingan bangsa" serta dianggap bertentangan dengan Pasal 240 ayat (1) UU Pemilu yang menyebutkan bahwa "Bakal calon anggota DPR, DPRD Provinsi dan DPRD Kabupaten/Kota adalah warga negara Indonesia dan harus memenuhi persyaratan: a. Tidak pernah dipidana penjara berdasarkan putusan pengadilan yang telah memperoleh kekuatan hukum tetap karena melakukan tindakan pidana yang diancam dengan pidana penjara 5 (lima) tahun atau lebih kecuali secara 
terbuka dan jujur mengemukakan kepada publik bahwa yang bersangkutan mantan narapidana”.

Selain itu, MA juga berpendapat bahwa ketentuan pada Peraturan KPU tersebut di atas bertentangan dengan Pasal 12 huruf d Undang-Undang Nomor 12 Tahun 2011 yang menyebutkan bahwa "Peraturan di bawah undang-undang berisi materi untuk menjalankan undang-undang sebagaimana mestinya", dalam hal ini MA berpendapat bahwa tidak ada perintah dari Pasal 240 Ayat (1) UU Pemilu untuk melarang mantan narapinana untuk mencalonkan diri menjadi anggota DPR, DPRD Provinsi dan DPRD Kabupaten/Kota, maka Peraturan KPU tersebut bertentangan dengan asas-asas pembentukan peraturan perundang-undangan yang baik.

Pemilu yang adil dan berintegritas sebagaimana menjadi semangat Peraturan KPU tersebut di atas, menjadi sebuah keniscayaan bahwa pencalonan anggota legislatif harus berasal dari figur yang bersih dan tidak pernah memiliki rekam jejak cacat integritas. Namun pengaturan terhadap pembatasan hak politik seorang warga negara harus dimuat dalam undang-undang, bukan diatur dalam peraturan perundang-undangan di bawah undang-undang. Itulah pertimbangan MA yang terakhir dalam mengabulkan permohonan atas pembatalan ketentuan Pasal 4 Ayat (1) Peraturan KPU Nomor 20 Tahun 2018.

Apabila dilihat secara teliti dan seksama, semua pertimbangan MA tersebut diatas sangat legalistikformal, pertimbangan hanya didasarkan pada ketentuan peraturan perundang-undangan, sehingga jelas terlihat positivisme hukum mendominasi alam fikiran MA dalam hal ini.

Putusan MA yang membatalkan Pasal 4 ayat (3) Peraturan KPU Nomor 20 Tahun 2018 termasuk di antara model putusan yang merampas realitas. Padahal, jika saja pendekatan itu tidak semata-mata mengutamakan kenormatifan hukum, tentu putusan itu akan jauh lebih berwibawa dan substantif, jauh memenuhi rasa keadilan yang hidup dalam masyarakat. Memang putusan MA itu tidak salah, tetapi putusan itu menjauhkan dari putusan hukum progresif yang dulu pernah dirintis oleh Satjipto Rahardjo. Seperti diketahui, bahwa gagasan hukum progresif lahir karena selama ini ajaran ilmu hukum positif (analytical jurisprudence) yang dipraktikkan pada 
realitas empirik tidak memuaskan.

Gagasan hukum progresif muncul karena prihatin terhadap kualitas penegakkan hukum di Indonesia saat ini yang sangat bertolak belakang dengan cita-cita hukum progresif. ${ }^{12}$

Progresivisme bertolak bahwa manusia pada dasarnya adalah baik, memiliki sifat-sifat kasih sayang, cinta dan memiliki kepedulian terhadap sesama. Dengan demikian, asumsi dasar hukum progresif dimulai dari hakikat dasar manusia. Bahwa hukum tidak diciptakan untuk dirinya sendiri seperti dalam gagasan positivisme hukum, melainkan hukum diciptakan untuk memenuhi kehendak dan kebutuhan manusia.

Hukum progresif mendudukan pemikirannya dalam posisi yang berbeda dengan pikiran rechtdogmatiek dan analytical jurisprudence, konsistensi hukum progresif dalam hal ketidaksepakatannya dengan positivisme hukum atau legisme hukum membuat dirinya membagi ruang dalam posisi filsafatnya dengan aliran filsat lain yakni filsafat hukum kodrat, mazhab sejarah legal realism dan freirechtslehre, sociological

${ }^{12}$ Erwin Moeslimin Singajuru, Kembali Ke Gagasan Hukum Progresif, Harian Kompas Senin, 5 November 2018, Hal 6. jurisprudence, interessenjurisprudenz dan critical legal studies.

Penolakan hukum progresif terhadap positivisme hukum terlihat dari pandangan yang memposisikan hukum tidak hanya sebagai teks belaka. Hukum sebagai teks itu diam dan hanya melalui peranan manusialah ia menjadi "hidup". Perilaku atau tindakan manusia itulah yang dapat menambah dan mengubah teks. Penegakkan hukum (law enforcement) adalah konsep normatif, di mana orang hanya tinggal mengaplikasikan apa yang ada dalam peraturan perundang-undangan. Praksis yang demikian itu juga disamakan dengan kerja mesin otomat (automaton). ${ }^{13}$ Gagasan ini jelas bersebrangan dengan pertimbangan MA dalam mengabulkan uji materi terhadap Peraturan KPU tersebut di atas, karena pertimbangan tersebut hanya didasarkan atas analisis yuridis peraturan perundang-undanganbelaka.

Hukum progresif secara sadar menempatkan kehadirannya dalam hubungan erat dengan manusia dan masyarakat. Dalam posisi demikian, hukum progresif dapat dikaitkan dengan developmental model hukum

13 Satjipto Rahardjo, Penegakkan Hukum Progresif, Kompas, Jakarta, 2010, Hal 15. 
Nonet dan Selznick, yaitu hukum memiliki tipe responsif. Dalam hal ini, hukum selalu dikaitkan dengan tujuantujuan di luar hukum itu sendiri. ${ }^{14}$ Secara singkat, bagi tatanan hukum responsif, hukum merupakan institusi sosial. Oleh karena itu, hukum dilihat lebih dari sekedar suatu sistem peraturan belaka, melainkan juga bagaimana hukum menjalankan fungsi-fungsi sosial dalam dan untuk masyaraktnya. ${ }^{15}$ Melihat hukum sebagai institusi sosial, berarti melihat hukum itu dalam kerangka yang luas, yaitu yang melibatkan berbagai proses dan kekuatan dalam masyarakat. Seperti diungapkan oleh Edwin $M$. Schur, sekalipun hukum itu napak sebagai perangkat norma-norma hukum, tetapi hukum merupakan hasil dari suatu proses sosial, sebab hukum dibuat dan diubah oleh usaha manusia dan hukum itu senantiasa berada di dalam keadaan yang berubah pula. ${ }^{16}$

Inti dari kedua teori ini memiliki banyak kesamaan atau titik temu di dalamnya. Dari segi hubungannya dengan manusia, teori hukum responsif dan teori hukum progresif memiliki keyakinan bahwa hukum

\footnotetext{
${ }^{14} \mathrm{Op}$., Cit.

15 Satjipto Rahardjo, Ilmu Hukum, PT. Citra Aditya Bakti, Bandung, 2006.

16 Satjipto Rahardjo, Hukum dan Masyarakat, Angkasa, Bandung, 1980.
}

untuk manusia, bukan manusia untuk hukum. Hal ini dikarenakan sudah seharusnya hukum itu diciptakan hanya atas dasar kehendak manusia, bukan kehendak yang lain. Kedua teori ini mengingatkan kita bahwa, tiada hukum yang hidup tanpa masyarakat. Masyarakat dengan segala macam impian, cita, harapan dan keperluan bahan material yang diperlukan dalam menyusun hukum. ${ }^{17}$

Hukum progresif mendahulukan kepentingan manusia yang lebih besar daripada menafsirkan hukum dari sudut "logika dan "peraturan" sebagaimana dipraktikan oleh lembaga peradilan seperti MA di atas. Hukum progresif tidak hanya berhenti pada kritik atas sistem hukum liberal. Hukum progresif mengetengahkan paham bahwa hukum itu tidak mutlak digerakkan oleh hukum positif atau hukum perundang-undangan, tetapi ia juga digerakkan pada arah nonformal. Oleh karena itulah, hukum progresif berasumsi bahwa hukum itu ada dan hadir untuk manusia. ${ }^{18}$

Lembaga peradilan seharusnya progresif, pengadilan yang progresif mengikuti maksim "Hukum adalah

17 Alda Rifada Rizqi, Koneksitas Teori Hukum Progresif dan Teori Hukum Responsif Dalam Rangka Mencapai Tujuan Hukum, Makalah, Program Pasca Sarjana Magister Hukum STHB, 2016.

${ }^{18} \mathrm{Op}$., Cit. 
untuk rakyat bukan sebaliknya”. Bila rakyat adalah untuk hukum, apa pun yang dipikirkan dan dirasakan rakyat akan ditepis karena yang dibaca adalah kata-kata undang-undang. Dalam hubungan ini, pekerjaan hakim bukan hanya teknisi undang-undang, tetapi juga mahluk sosial. Karena itu, pekerjaan hakim sungguh mulia karena ia bukan hanya memeras otak, tetapi juga nuraninya. Menjadi makhluk sosial akan menempatkan hakim di tengah hiruk-pikuk masyarakat, keluar dari gedung pengadilan. Bahkan ada yang mengatakan, seorang hakim sudah tidak ada bedanya dengan wakil rakyat. Bila ia berada di tengah masyarakat, berarti ia berbagi sukaduka, kecemasan, penderitaan, harapan, seperti yang ada di masyarakat. Melalui putusanputusannya, hakim suka disebut mewakili suara mereka (rakyat) yang terwakili dan kurang terwakili. ${ }^{19}$

Seperti dipahami penegakkan hukum mengandung supremasi nilai, yaitu keadilan. Namun di alam hukum modern khususnya di Indonesia, terkesan hukum bukan lagi tempat mencari keadilan, tetapi pengadilan kemudian bergeser dan berkutat pada hlm. 191-192. aturan main dan prosedur. Dengan kata lain, pengadilan hanya sebagai lembaga penerapan peraturan perundang-undangan dan prosedur saja. Pada hukum demikian ini, sejatinya hukum telah kehilangan rohnya sebagai house of justice.

Teori hukum menyatakan bahwa hukum harus memenuhi tiga kebenaran, kebenaran filosofis, kebenaran sosiologis, dan kebenaran formal. Putusan hukum harus memenuhi kebenaran filosofis (kebenaran universal/ hati nurani), kebenaran sosiologis (nilai kebenaran yang dianut masyarakat), dan kebenaran formal (tertulis dalam aturan negara).

Penganut kebenaran formal (hukum positif) tidak akan mempersoalkan apakah hukum yang berlaku dan/ atau diberlakukan dinilai adil atau tidak adil. Penganut positivisme hukum akan merasa sudah memenuhi kewajibannya apabila telah memenuhi ketentuan yang tertulis dalam undangundang. Bagi penganut positivisme hukum tidak penting adakah putusan hukum yang sesuai atau tidak sesuai dengan nilai-nilai kebenaran yang dianut masyarakat (kebenaran sosiologis) ataupun nilai kebenaran uiversal/ kebenaran yang sejalan dengan hati-nurani (kebenaran 
filosofis). Hukum bersifat formalistislegalistik. Secara ekstrem, Karl Bergbohm $^{20}$ mengatakan bahwa “....juga hukum yang paling jahat, sejauh diadakan sesuai dengan ketentuan-ketentuan formal haus diakui keberlakuannya...."

Namun hal yang berbeda dikatakan oleh Satjipto Rahardjo, ${ }^{21}$ bahwa hukum tidak boleh hanya berorientasi pada kekuasaan (yang dengan pelaksanaan hukum bisa dilaksanakan), atau hanya pada kepentingan umum (yang merupakan sandaran kepercayaan publik), hukum harus pula memenuhi "logika kepatutan sosial (social reasonableness)". Negara hukum tidak sama dengan negara undangundang, negara hukum juga bukan negara prosedur.

Oleh karena itu, kualitas hukum dalam negara demokrasi akan dinilai dari sejauh mana ketentuan hukum mengindahkan dan/ atau mengakomodasi nilai-niai kebenaran filosofis dan kebenaran sosiologis. Kualitas hukum dalam negara demokrasi adalah seperti yang

\footnotetext{
${ }^{20}$ Karl Bergbohm, dikutip oleh Hendarmin Ranadireksa, Arsitektur Konstitusi Demokratik, Fokusmedia, Bandung, 2015, hlm. 221.

21 Satjipto Rahardjo, Harian Kompas 7 Oktober 2004.
}

dikatakan oleh Habermas, 22 "Hanya bila semua pihak yang akan terkena dampak suatu norma hukum bisa menerima konsekuensi dan efek sampingnya, kepatuhan umum atas hukum itu dapat diharapkan memenuhi kepentingan semua orang”.

Artinya bahwa kualitas demokrasi ditentukan sejauh mana peran serta rakyat dalam proses pembuatan hukum (antara lain dengan menampung pendapat masyarakat dan/atau menjaring opini publik) dan sejauhmana bila rakyat ikut diperankan dalam ikut memberikan penilaian atas pelaksanaan hukum dan kinerja penegak hukum.

Kedaulatan rakyat mengandung makna bahwa rakyat harus memiliki hak dan kewenangan utuk menolak hukum yang tidak sesuai dengan aspirasi dan kepentingannya. Sama halnya dalam pembuatan keputusan hakim, sebagaimana disebutkan di atas bahwa hakim harus menjadi representasi masyarakat, hakim harus meletakkan telinganya ke jantung masyarakat, dengan demikian itulah pengadilan kita akan melahirkan putusan-putusan yang progresif.

22 Franz Magnis-Suseno, Etika Politik, Prinsip-prinsip Moral Dasar Kenegaraan Modern, Gramedia Pustaka Utama, Jakarta, 1999, hlm. 101. 


\section{PENUTUP}

Sesuai dengan ketentuan pasal 24 Ayat (1) UUD NRI 1945 menyebutkan bahwa kekuasaan kehakiman merupakan kekuasaan yang merdeka untuk menyelenggarakan peradilan guna menegakkan hukum dan keadilan. Hukum dan keadilan memiliki pengertian yang jauh lebih luas daripada kata-kata yang tertulis dalam undang-undang. Dalam hal ini, sesuai dengan ketentuan selanjutnya, dalam pasal 24 A Ayat (1) bahwa MA berwenang mengadili pada tingkat kasasi, menguji peraturan perundangundangan di bawah undang-undang terhadap undang-undang, dan mempunyai wewenang lainnya yang diberikan oleh undang-undang.

Masyarakat Indonesia adalah masyarakat yang memiliki pandangan luhur akan kepribadian bangsanya, menjadi kesepakatan bersama bahwa prilaku koruptif pejabat negara tidak bisa ditoleransi, perilaku tersebut telah merugikan semua sendi kehidupan, bahkan lebih jauh perilaku koruptif telah melanggar hak asasi warga negara. Menjadi hal yang wajar, apabila warga negara menginginkan pemimpin yang teruji integritasnya, memiliki rekam jejak yang baik, karena di tangan merekalah nasib masyarakat banyak ditentukan.

Dalam rangka mengakomodasi kepentingan rakyat sebagai pemegang kedaulatan, KPU sebagai penyelenggara pemilu dianggap tepat mengeluarkan Peraturan KPU Nomor 20 Tahun 2018, karena untuk memenuhi rasa keadilan rakyat mantan narapidana korupsi tidak diperkenankan lagi mencalonkan diri menjadi anggota legislatif baik tingkat pusat dan daerah. Putusan MA No. 46 P/HUM/2018 dengan sendirinya menjauhkan diri dari progresifitas hukum, karena mengedepankan aspekaspek formal-prosedural dalam pertimbangannya sehingga putusan tersebut terkesan legalistikpositivistik. Seyogyanya, berlandasakan pemikiran hukum progresif MA memiliki komitmen yang sama dalam mengakomodasi keinginan masyarakat yang tidak ingin terus dirugikan atas prilaku koruptif pejabat negara, melalui proses pemilihan umum yang berintegritas.

\section{DAFTAR PUSTAKA}

\section{Buku-Buku}

Agussalim Andi Gadjong. 2007. Pemerintah Daerah Kajian Politik dan Hukum. Ghalia Indonesia, Bogor. 
Dedi Mulyadi. 2013. Perbandingan Tindak Pidana Pemilu Legislatif Dalam Perspektif Hukum di Indonesia. Refika Aditama, Bandung.

Franz Magnis-Suseno. 1999. Etika Politik, Prinsip-prinsip Moral Dasar Kenegaraan Modern. Gramedia Pustaka Utama, Jakarta.

Hendarmin Ranadireksa. 2015. Arsitektur Konstitusi Demokratik. Fokusmedia, Bandung.

I Gde Pantja Astawa dan Suprin Na'A. 2015. Memahami Ilmu Negara \& Teori Negara. Refika Aditama, Bandung.

Jimly Asshidiqie. 2006. Perkembangan dan Konsolidasi Lembaga Negara Pasca Reformasi. Sekretaris Jendral dan Kepaniteraan Mahkamah Konstitusi Republik Indonesia, Jakarta.

Moh. Mahfud MD. 2003. Demokrasi dan Konstitusi di Indonesia. Rineka Cipta, Jakarta.

Philipus M. Hadjon. 2002. Pengantar Hukum Administrasi IndonesiaIntroduction to Indonesian Administrative Law. Gadjah Mada University Press, Yogyakarta.

Ridwan HR. Hukum Administrasi Negara. 2006. Raja Grafindo Persana, Jakarta.

Satjipto Rahardjo. 1980. Hukum dan Masyarakat. Angkasa, Bandung.

\section{Ilmu}

Hukum. PT. Citra Aditya Bakti, Bandung.
. 2010. Penegakkan Hukum Progresif. Kompas, Jakarta.

\section{Lain-Lain}

Alda Rifada Rizqi. 2016. Koneksitas Teori Hukum Progresif dan Teori Hukum Responsif Dalam Rangka Mencapai Tujuan Hukum. Makalah. Program Pasca Sarjana Magister Hukum Sekolah Tinggi Hukum Bandug (STHB), Bandung.

Bagir Manan. 2001. Wewenang Provinsi, Kabupaten dan Kota dalam Rangka Otonomi Daerah, Makalah pada Seminar Nasional Pengembangan Wilayah dan Pengelolaan Sumber Daya Alam di Kawasan Pesisir dalam Rangka Penataan Ruang. $\quad$ Fakultas Hukum Universitas Padjajaran, Bandung.

Erwin Moeslimin Singajuru. 2018. Kembali Ke Gagasan Hukum Progresif. Harian Kompas, Jakarta.

https://www.antikorupsi.org.id/siaranpers/kpu-harus-jalan-teruslarang-mantan-napi-korupsinyaleg 